Abstracta Iranica Iranica

Revue bibliographique pour le domaine irano-aryen

Volume 37-38-39 | 2018

Comptes rendus des publications de 2014-2016

Denis Hermann. Kirmānī Shaykhism and the ijtihād. A Study of Abū al-Qāsim Khān Ibrāhìmì's Ijtihād wa taqlìd

\title{
Sacha Alsancakli
}

\section{OpenEdition}

1 Journals

\section{Édition électronique}

URL : http://journals.openedition.org/abstractairanica/47123

DOI : 10.4000/abstractairanica.47123

ISBN : 1961-960X

ISSN : 1961-960X

Éditeur :

CNRS (UMR 7528 Mondes iraniens et indiens), Éditions de l'IFRI

Référence électronique

Sacha Alsancakli, « Denis Hermann. Kirmānī Shaykhism and the ijtihād. A Study of Abū al-Qāsim Khān Ibrāhimiı's ljtihād wa taqlïd », Abstracta Iranica [En ligne], Volume 37-38-39 | 2018, document 3, mis en ligne le 30 décembre 2018, consulté le 29 septembre 2020. URL : http://journals.openedition.org/ abstractairanica/47123; DOI : https://doi.org/10.4000/abstractairanica.47123

Ce document a été généré automatiquement le 29 septembre 2020.

Tous droits réservés 


\title{
Denis Hermann. Kirmānī Shaykhism and the ijtihād. A Study of Abū al- Qāsim Khān Ibrāhìmì's Ijtihād wa taqlìd
}

\author{
Sacha Alsancakli
}

\section{RÉFÉRENCE}

Denis Hermann. Kirmānī Shaykhism and the ijtihād. A Study of Abū al-Qāsim Khān Ibrāhīmī's Ijtihād wa taqlìd. Würzburg : Ergon Verlag, 2015, 50 p., (Bibliotheca Academica, Orientalistik, Band 24), ISBN : 978-3-95650-097-8

1 Ce travail de Denis Hermann est une étude de l'ouvrage Ijtihād wa taqlid, traité de fiqh composé en 1362/1943 par Abū al-Qāsim Khān Ibrāhīmī (m. 1969), maître de l'école shaykhī de Kirmān. D'abord écrit en arabe, le traité fut ensuite traduit en persan et c'est cette traduction persane qui est l'objet de la présente étude (p. 17). Le traité d'Abū al-Qāsim Khān est fondé sur le rejet de l'ijtihād, considéré par Abū al-Qāsim Khān comme une « conjecture (zann) » et une « innovation condamnable (ikhtirā')» (p. 25) liée au sunnisme. Au-delà de ce rejet de l'ijtihād, s'inscrivant dans la droite lignée de l'école akhbārī, l'autre caractéristique majeure du shaykhisme kirmānī réside dans la doctrine du rukn-i rābi', ou " quatrième pilier ", doctrine impliquant la foi en une "élite spirituelle [chiite] responsable du lien entre l'Imām de l'Époque et les croyants » (p. 14).

2 L'étude claire et concise de l'A. est divisée en quatre parties, encadrées par quelques pages d'introduction et de conclusion : la première partie est consacrée à l'essor du shaykhisme (p.11-14), la deuxième partie propose une courte biographie d'Abū alQāsim Khān Ibrāhīmī et une présentation de son ouvrage, l'Ijtihād wa taqlīd (p. 15-17), et la troisième partie pose la question de l'héritage akhbārī dans la doctrine shaykhī (p. 19-24). Ces trois premières parties font figure d'approche au sujet principal traité par l'A., à savoir l'étude de l'Ijtihād wa taqlīd d'Abū al-Qāsim Khān, sujet abordé dans la quatrième partie (p. 25-48). L'A. y développe la position du maître shaykhī sur l'ijtihād 
(p. 25-26), sur la notion de muqallid (p. 26-31), sur les origines et le développement de l' ijtihād en contexte chiite (p. 31-40), sur les relations entre le figh et la raison en islam (p. 40-43), avant de consacrer une dernière section aux propositions d'Abū al-Qāsim Khān et à son approche ascétiste et quiétiste du figh (p. 44-48).

\section{AUTEURS}

\section{SACHA ALSANCAKLI}

Université Sorbonne nouvelle, Mondes iranien et indien 